\title{
Synthesis and Application of a Functionalized Polystyrene Resin for On-Line Preconcentration and Determination of Cobalt(II) in Water Samples by Flow Injection/FAAS
}

\author{
Mansour Arab Chamjangali,* Laleh Sharif-Razavian, Bahram Bahramian \\ and Ghadamali Bagherian
}

College of Chemistry, Shahrood University of Technology, P.O. Box 36155-316, Shahrood, Iran

\begin{abstract}
Foi desenvolvido um método simples e sensível de espectrometria de absorção atômica em chama com injeção por fluxo para a pré-concentração em linha e determinação de níveis traço de cobalto(II). Uma mini-coluna empacotada com poliestireno clorometilado e funcionalizado com $\mathrm{N}, \mathrm{N}-$ bis(naftilidenoimina)dietilenotriamina (PS-NAPdien) foi utilizada para o enriquecimento em sistema de fluxo de cobalto(II) a partir de amostras em $\mathrm{pH}$ 7.0. Todas as variáveis químicas e de fluxo foram otimizadas. Sob condições ótimas, o gráfico de calibração foi linear na faixa de concentração de 1.0-80.0 e 0.30-0.40 $\mu \mathrm{g} \mathrm{L}^{-1}$ para a pré-concentração de volumes de soluções de 10.0 e $20.0 \mathrm{~mL}$, respectivamente. Os valores de limites de detecção para a pré-concentração de amostras para volumes de 10.0 e $20.0 \mathrm{~mL}$ foram 0.75 e $0.25 \mu \mathrm{g} \mathrm{L}^{-1}$, respectivamente. Um fator de enriquecimento de 110 para um volume de amostra de $10.0 \mathrm{~mL}$ foi obtido. Os desvios padrão relativos para 10 replicatas de cobalto(II) nos níveis de 10.0 e $60.0 \mu \mathrm{g} \mathrm{\textrm {L } ^ { - 1 }}$ foram 4.7 e $3.3 \%$, respectivamente. A exatidão do método proposto foi demonstrada a partir da determinação de $\mathrm{Co}(\mathrm{II})$ em diferentes amostras de água usando experimentos de adição e recuperação.
\end{abstract}

A simple and sensitive flow injection-flame atomic absorption spectrometric (FI-FAAS) method was developed for on-line preconcentration and determination of trace levels of cobalt(II). A mini-column packed with a chloromethylated polystyrene, functionalized with $\mathrm{N}, \mathrm{N}$-bis(naphthylideneimino)diethylenetriamine (PS-NAPdien) was used for on-line enrichment of cobalt(II) from samples at $\mathrm{pH}$ 7.0. All chemical and flow variables were optimized. Under the optimum conditions, calibration graph was linear over the concentration ranges of 1.0-80.0 and $0.30-40.0 \mu \mathrm{g} \mathrm{L}^{-1}$ for preconcentration of 10.0 and $20.0 \mathrm{~mL}$ solutions, respectively. The limits of detection (LODs) values for preconcentration of 10.0 and $20.0 \mathrm{~mL}$ sample solutions were 0.75 and $0.25 \mu \mathrm{g} \mathrm{L}{ }^{-1}$, respectively. An enrichment factor of 110 for a sample volume of $10.0 \mathrm{~mL}$ was obtained. The relative standard deviations for 10 replicate determinations of cobalt(II) at the 10.0 and $60.0 \mu \mathrm{g} \mathrm{L}^{-1}$ levels were 4.7 and $3.3 \%$, respectively. The accuracy of the proposed method was demonstrated by determining $\mathrm{Co}(\mathrm{II})$ in different spiked water samples.

Keywords: flame atomic absorption spectrometry, on-line preconcentration, flow injection, polystyrene, cobalt(II)

\section{Introduction}

Cobalt is an essential element for humans and animals because it is associated with the synthesis of vitamin $\mathrm{B}_{12}$. On the other hand, cobalt is also classified as an environmental toxin. It can harm the natural environment, even at low concentrations, through its inherent toxicity and its tendency to accumulate in the food chain. Therefore, it is clear that the determination of trace amounts of cobalt in biological and environmental samples plays an important

\footnotetext{
*e-mail: marab@shahroodut.ac.ir
}

role in the fields of environmental surveillance, food control, medicine and toxicology.

Atomic spectrometric methods are extensively employed for the quantification of metal species. ${ }^{1}$ In particular, FAAS has been one of the most applied methods for the determination of inorganic elements in a variety of samples. ${ }^{2}$ However, its main problem is the low sensitivity for some elements at the $\mu \mathrm{g} \mathrm{L}^{-1}$ level. To improve FAAS sensitivity and selectivity, preconcentration procedures are frequently required. ${ }^{3}$

Solid phase extraction (SPE) has found increasing application for the preconcentration of trace metals and 
elimination of matrix interference prior to AAS analysis due to advantages such as accuracy, high sample throughput, high enrichment factor, and low consumption of organic solvents. Despite all those advantages, batch-mode of SPE is time consuming, requires large sample or reagent volumes, and has the potential for contamination and analyte loss. ${ }^{4}$ Those batch-mode drawbacks can be overcome to a great extent, by applying on-line methods, in addition to enhancing enrichment factors. ${ }^{5}$ Flow injection (FI) separation and preconcentration coupled to FAAS has become a popular method for determination of trace metals due to its low cost and high sample throughput. ${ }^{6,7}$ The most critical parameter in an on-line preconcentration method based on SPE is the nature and properties of the sorbent material. ${ }^{8}$ The main requirements for a sorbent material are: fast and quantitative adsorption/elution, regeneration ability, high capacity, accessibility, and chemical and mechanical resistance. Up to now, various SPE sorbents have been employed for the preconcentration and determination of cobalt both in batch and FI modes. Some of these sorbents include $\mathrm{C}-18$ bonded silica, ${ }^{9-12}$ activated carbon, ${ }^{13-16}$ functionalized cellulose, ${ }^{17,18}$ knotted reactor, ${ }^{19-22}$ modified alumina, ${ }^{23-26}$ silica gel modified with glycerol, ${ }^{27}$ and C-60 fullerene. ${ }^{12}$ Among these solid phase sorbents, a good alternative to achieve very versatile systems that can be applied to a wide range of samples is the use of polymeric solid supports functionalized with complexing reagents. ${ }^{28-34}$ Some advantages for the use of polymeric solid supports include low cost, simple preparation, high porosity (and therefore high available surface area), and stability in both acidic and basic media. ${ }^{35}$

In this work, the preparation of a new type of chemically modified polystyrene and its application as a packing material for on-line preconcentration followed by determination of cobalt by FAAS is reported. The chelating resin was prepared by chemical functionalization of chloromethylated polystyrene with $\mathrm{N}, \mathrm{N}$-bis(naphthylideneimino)diethylenetriamine (NAPdien) (II). Because of the resin chemical resistance and long lifetime, the column did not need any regeneration or repacking and remained unaltered after the preconcentration and elution steps. The mini-column packed with this newly functionalized polystyrene was used for rapid FI-FAAS preconcentration and determination of trace amounts of cobalt in various water samples.

\section{Experimental}

\section{Reagents and solutions}

Ultra-pure deionized water from a Milli-Q water purification system (Millipore, Bedford, MA, USA) was used to prepare all solutions. All chemicals used were of analytical reagent grade provided from Merck (Germany) or Fluka (Switzerland), and no previous purification was necessary. The laboratory glassware was kept overnight in a $10 \%(\mathrm{v} / \mathrm{v})$ nitric acid solution. Before using, the glassware was washed with deionized water.

A cobalt(II) stock solution (1000 $\left.\mathrm{mg} \mathrm{mL}^{-1}\right)$ was prepared by dissolving $0.4938 \mathrm{~g}$ of $\mathrm{Co}\left(\mathrm{NO}_{3}\right)_{2} \cdot 6 \mathrm{H}_{2} \mathrm{O}$ in a $100 \mathrm{~mL}$ volumetric flask. Working solutions were prepared daily from the stock solution by serial dilution with deionized water. A phosphate buffer solution was prepared by mixing appropriate volumes of $0.15 \mathrm{~mol} \mathrm{~L}^{-1} \mathrm{Na}_{2} \mathrm{HPO}_{4}$ and $0.15 \mathrm{~mol} \mathrm{~L}^{-1} \mathrm{KH}_{2} \mathrm{PO}_{4}$, and adjusting the $\mathrm{pH}$ to 7.0 using a $\mathrm{pHmeter}$. The eluent solution was prepared by appropriate dilution of concentrated hydrochloric acid (Merck) with deionized water to give a final concentration of $2.0 \mathrm{~mol} \mathrm{~L}^{-1}$. Chloromethylated polystyrene (cross-linked with $2 \%$ divinylbenzene, $4-5 \% \mathrm{Cl}$ content, $1.14-1.40 \mathrm{mmol} \mathrm{g}^{-1} \mathrm{Cl}$ ) was used in preparation of the sorbent.

\section{Preparation of the ligand (NAPdien) (II)}

The ligand NAPdien was prepared according to method described in the literature. ${ }^{36,37} 12.2 \mathrm{~g}(0.10 \mathrm{~mol})$ of 2-hydroxy-1-naphthaldehyde was dissolved in $75 \mathrm{~mL}$ of methanol, and $25 \mathrm{~mL}$ of a $2.0 \mathrm{~mol} \mathrm{~L}^{-1}$ diethylenetriamine solution in methanol was added. The reaction mixture thus obtained was refluxed on a water bath for $1 \mathrm{~h}$. After reducing the volume of the solvent to $c a .50 \mathrm{~mL}$, the content was transferred into a beaker and excess solvent was evaporated under a current of air. The viscous yellow-red oil obtained was further dried in vacuum. The purity of the ligand was then checked by elemental analysis, infrared spectroscopy, and electronic absorption spectra.

Preparation of polystyrene- $N, N$-bis(naphthylideneimino) diethylenetriamine (PS- NAPdien) (III)

Chloromethylated polystyrene ( $2.0 \mathrm{~g})$ was allowed to swell in dioxane $(30 \mathrm{~mL})$ for $2 \mathrm{~h}$. Then, $30 \mathrm{~mL}$ of a $0.60 \mathrm{~mol} \mathrm{~L}^{-1}$ solution of $\mathrm{N}, \mathrm{N}-$ bis(naphthylideneimino) diethylenetriamine in dioxane was added, and the mixture was heated at $80^{\circ} \mathrm{C}$ in an oil bath with mechanical stirring for $48 \mathrm{~h}$. After cooling to room temperature, the yellow resin beads were filtered, washed with dioxane solution and then with methanol, and dried in an air oven at $120^{\circ} \mathrm{C}$ for $1 \mathrm{~h}$. Successful functionalization of the polymer was confirmed by elemental analysis, IR spectrum, and scanning electron microscopy (SEM). 


\section{Preparation of mini-column}

The mini-column was manufactured in the laboratory with a polyethylene tubing of $10 \mathrm{~cm}$ length and $2.0 \mathrm{~mm}$ internal diameter, and packed with about $135 \mathrm{mg}$ of the sorbent. The column ends were fitted with glass wool to retain the sorbent inside the tube. The packed mini-column was initially washed with $2.0 \mathrm{~mol} \mathrm{~L}^{-1} \mathrm{HCl}$ and then with water before use. Because of the unlimited lifetime of the packing material, the column did not need any regeneration or repacking, and its performance was stable during all experiments.

\section{Instrumentation}

A schematic diagram of the flow manifold used is presented in Figure 1. A variable flow rate peristaltic pump with 12 channels Model 5201 (Heidolph, Germany) equipped with Tygon ${ }^{\circledR}$ tubes was used to pump a sample stream through the manifold. PTFE tubing was used for the manifold lines. The six-way rotary injection valve Model 5011 (Supelco, Saint Louis, MO, USA) allowed the eluent to be directly injected into a loop and pass through the mini-column (with $100 \mathrm{~mm}$ of length and $2.0 \mathrm{~mm}$ i.d) located between the injection valve and the FAAS system. A Shimadzu AA-670 FAAS (Kyoto, Japan) was used for Co determination under the conditions recommended by the manufacturer. A Philips XL-30 scanning electron microscope (Eindhoven, Netherland) was used to record the sorbent material surface images. To record the UV-visible spectra, a Shimadzu UV-160 (Japan) spectrophotometer with $1.0 \mathrm{~cm}$ quartz cells was used. IR spectra were recorded
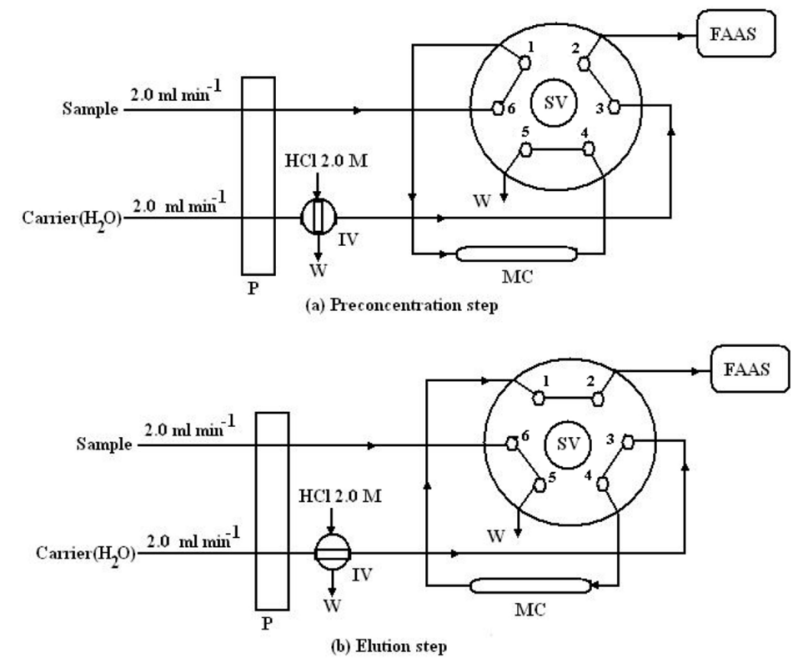

Figure 1. Schematic diagram of FI-manifold and the two operation sequences for cobalt(II) determination by FAAS. (a) Preconcentration and (b) elution steps. P: peristaltic pump; IV: injection valve; SV: selection valve; $\mathrm{MC}$ : mini-column; $\mathrm{W}$ : waste. on a Shimadzu IR-470 (Japan) spectrometer. Measurements of $\mathrm{pH}$ were made using a Metrohm $691 \mathrm{pH}$-meter (Zofingen, Switzerland) equipped with a combined glasssaturated calomel electrode.

\section{Cobalt on-line preconcentration and determination procedure}

The simple FI manifolds presented in Figure 1 were used for preconcentration and determination of cobalt(II) via the eluent injection strategy. At first (Figure 1a), the selection valve allowed a known volume (e.g., $10 \mathrm{~mL}$ ) of the standard or sample solutions (buffered at $\mathrm{pH} 7.0$ with phosphate buffer) to pass through the mini-column at a flow rate of $2.0 \mathrm{~mL} \mathrm{~min}^{-1}$ for $5.0 \mathrm{~min}$ to load the sample into the mini-column packed with the functionalized polystyrene. The baseline signal recorded during the preconcentration step was always stable and equal to zero. During this step, $200 \mu \mathrm{L}$ of a $2.0 \mathrm{~mol} \mathrm{~L}^{-1}$ hydrochloric acid solution (as eluent) was manually loaded into the injection valve loop. At the end of the preconcentration step, the selection valve was rotated and the carrier solution passed through the

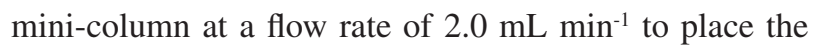
eluent plug into the mini-column (Figure 1b). The selection valve was kept at this position for additional $30 \mathrm{~s}$ to ensure that the entire eluent volume was flushed out of the loop, and that the adsorbed cobalt was eluted and transported to the FAAS for determination. Afterwards, the valve was switched back to its initial position (Figure 1a) for the next run. The transient signal was recorded and the absorbance value was used for quantitative analysis. Three replicate measurements were made for each sample.

\section{Results and Discussion}

It is well-known that polydentate ligands such as Schiff's bases form strong complexes with transition metal ions. N,N-bis(naphtilidineimino)diethylenetriamine (II), in Scheme 1 is a Schiff's base ligand with two oxygen and three nitrogen donating groups. Thus, we decided to examine the possibility of imobilizing NAPdien on chloromethylated polystyrene (I) and to evaluate this compound capability as a suitable sorbent for preconcentration and separation of metal ions via solid phase extraction in a mini-column flow injection system.

\section{Synthesis and characterization of the sorbent material}

NAPdien (II) can be immobilized on chloromethylated polystyrene polymer (I) to form functionalized PS- NAPdien (III) according to the following reaction: 


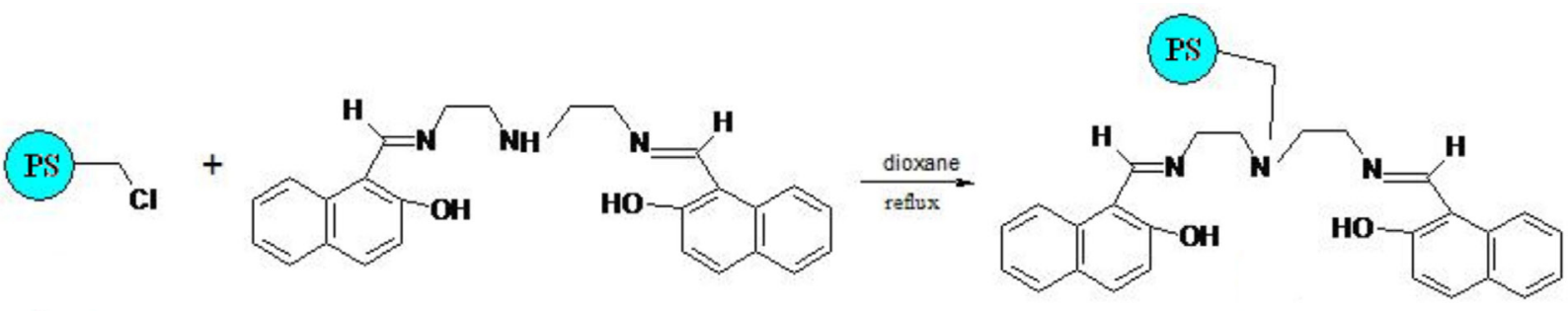

Scheme 1. Synthesis of PS-NAPdien resin and its proposed structure (III). PS: Polystyrene.

The resulting functionalized polymer (PS-NAPdien) was characterized by employing elemental analysis, infrared spectrometry, and SEM. The $\mathrm{N}$ content of the resin was found to be $3.45 \%\left(0.82 \mathrm{mmol} \mathrm{g}^{-1}\right)$, which indicates that only $58 \%$ of the total chlorines were substituted by the amine. The sharp $\mathrm{C}-\mathrm{Cl}$ peak at $1264 \mathrm{~cm}^{-1}$ from the $\mathrm{CH}_{2} \mathrm{Cl}$ groups in the chloromethylated polystyrene (starting polymer) was either practically omitted or seen as a weak band in the IR spectrum of PS-NAPdien. The PS-NAPdien IR spectrum with both a(the sentence is incomplete) in the region $1629-1550 \mathrm{~cm}^{-1}$, assigned to the vibration of a $\mathrm{C}=\mathrm{N}$ bond (azomethine), and a medium intensity band due to stretching of $\mathrm{C}-\mathrm{N}$ at $1193 \mathrm{~cm}^{-1}$, clearly indicate the immobilization of the ligand on the support via a covalent bond. SEMs were recorded for a single bead of pure chloromethylated polystyrene (Figure $2 \mathrm{a}$ ) and polymeranchored ligand (PS-NAPdien) (Figure 2b) to observe the morphological changes. As expected, the pure polystyrene bead had a smooth and flat surface, while the PS-NAPdien bead showed roughening of the top layer, which is another evidence to confirm the loading of the ligand on the support.

\section{Optimization of the preconcentration procedure}

In order to obtain highly sensitive, accurate, and reproducible results, the influence of various chemical and flow parameters on $\mathrm{Co}$ (II) the sensitivity were studied using an univariate optimization approach.

The sorption of cobalt(II) by PS-NAPdien was studied at different $\mathrm{pH}$ values. For this purpose, $10 \mathrm{~mL}$ of $30.0 \mu \mathrm{g} \mathrm{L}^{-1}$ cobalt (II) solutions buffered at different $\mathrm{pHs}$ (ranging from 3.0-11.0) were introduced onto the column at a flow rate of $2.0 \mathrm{~mL} \mathrm{~min}^{-1}$. The adsorbed cobalt(II) was eluted by injecting $200 \mu \mathrm{L}$ of $2.0 \mathrm{~mol} \mathrm{~L}^{-1} \mathrm{HCl}$, and the corresponding analytical signals were recorded. As it can be seen in Figure 3, the optimum $\mathrm{pH}$ range was around 6.5-8.0. Thus, all sample and standard solutions were buffered at $\mathrm{pH} 7.0$ with a $0.040 \mathrm{~mol} \mathrm{~L}^{-1}$ phosphate buffer solution.

The nature of the eluent has a significant effect on the desorption process. According to preliminary experiments, it was found that elution of preconcentrated cobalt ions a)

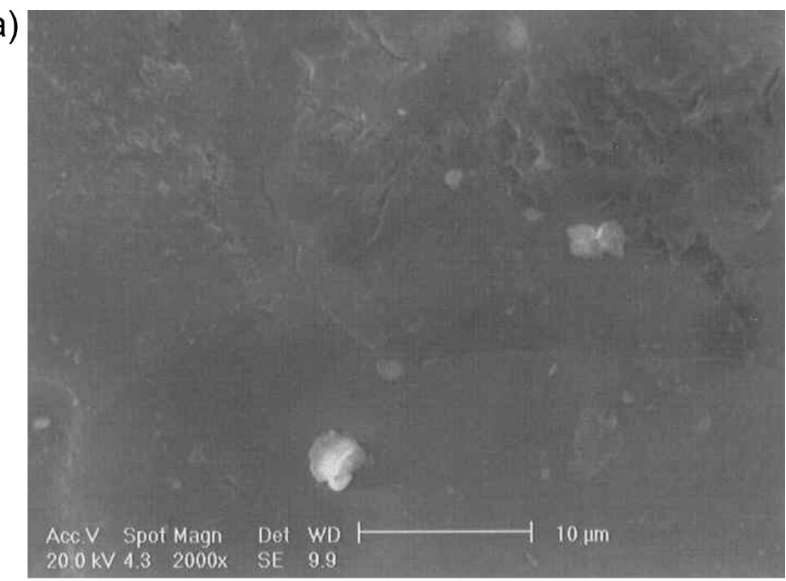

b)

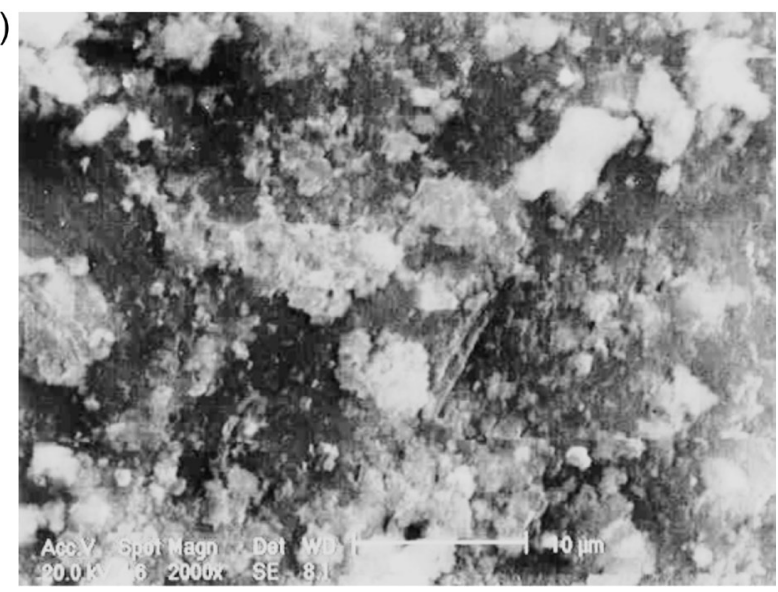

Figure 2. SEMs for a single bead of (a) pure chloromethylated polystyrene, and (b) polymer-anchored ligand (PS-NAPdien).

could be made by breaking the metal-chelate bond using mineral acids. Sulfuric, nitric, and hydrochloric acids solutions with the same concentrations were used for elution. The results have shown that hydrochloric acid is the best choice since better sensitivity and recovery values were obtained with this eluent.

The effect of eluent concentration on the absorption signal of cobalt was examined in the range $0.20-2.5 \mathrm{~mol} \mathrm{~L}^{-1}$ with a constant injection volume of $200 \mu \mathrm{L}$. An eluent concentration higher than $2.5 \mathrm{~mol} \mathrm{~L}^{-1}$ was not studied since different parts of the nebulizer system could be affected. 


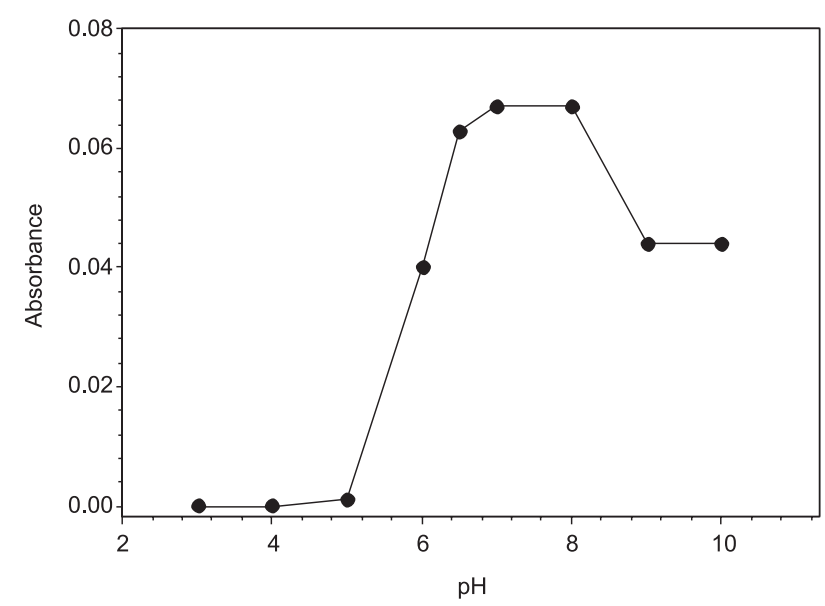

Figure 3. Effect of sample solution acidity on Co(II) absorbance. Conditions: preconcentration of $10 \mathrm{~mL}$ of a $30.0 \mu \mathrm{g} \mathrm{L} \mathrm{L}^{-1} \mathrm{Co}$ (II) solution at a flow rate of $2.0 \mathrm{~mL} \mathrm{~min}^{-1}$ on a $10.0 \mathrm{~cm}$ mini-column and elution with $200 \mu \mathrm{L}$ of $1.5 \mathrm{~mol} \mathrm{~L}^{-1} \mathrm{HCl}$ at a flow rate of $2.0 \mathrm{~mL} \mathrm{~min}^{-1}$.

Results (Figure 4) showed that the absorbance increased as the $\mathrm{HCl}$ concentration increased up to $1.5 \mathrm{~mol} \mathrm{~L}^{-1}$ and then remained constant with further increase in the eluent concentration. Thus, to insure quantitative elution of adsorbed cobalt, a $\mathrm{HCl}$ concentration of $2.0 \mathrm{~mol} \mathrm{~L}^{-1}$ was chosen for subsequent studies.

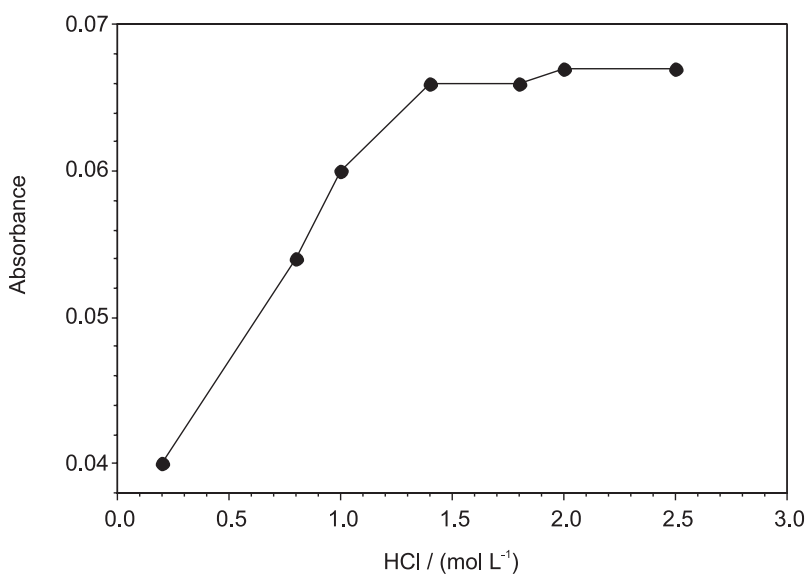

Figure 4. Effect of eluent concentration on $\mathrm{Co}(\mathrm{II})$ absorbance. Conditions: preconcentration of $10 \mathrm{~mL}$ of a $30.0 \mu \mathrm{g} \mathrm{L}{ }^{-1} \mathrm{Co}(\mathrm{II})$ solution buffered at $\mathrm{pH}$ 7.0 at a flow rate of $2.0 \mathrm{~mL} \mathrm{~min}^{-1}$ on a $10.0 \mathrm{~cm}$ mini-column and elution with $200 \mu \mathrm{L}$ of $\mathrm{HCl}$ at a flow rate of $2.0 \mathrm{~mL} \mathrm{~min}^{-1}$.

In on-line preconcentration systems with time-based sampling, the sample flow rate determines the contact time between the sample solution and the sorbent. The effect of the sample flow rate was studied in the range 1.0-3.6 $\mathrm{mL} \mathrm{min}^{-1}$ by passing aliquots of $10 \mathrm{~mL}$ of 10.0 and $30.0 \mu \mathrm{g} \mathrm{L} \mathrm{L}^{-1}$ cobalt(II) solutions, at $\mathrm{pH} 7.0$, through a $10 \mathrm{~cm}$ sorbent packed column containing sorbent. Results (Figure 5) showed that the absorbance increased with increase in sample flow rate up to $2.0 \mathrm{~mL} \mathrm{~min}^{-1}$ and decreased above it probably due to insufficient mass

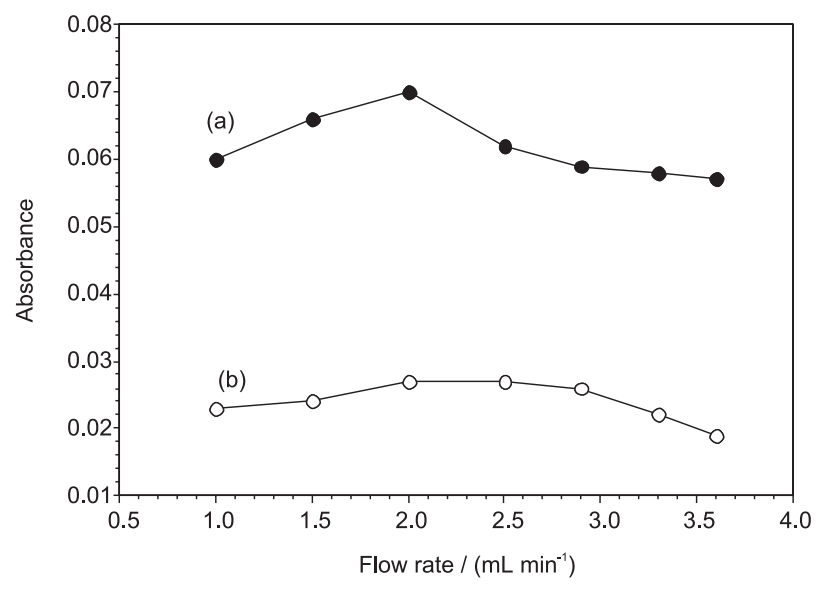

Figure 5. Effect of sample flow rate on $\mathrm{Co}$ (II) absorbance. Conditions: preconcentration of $10 \mathrm{~mL}$ of a) 30.0 and b) $10.0 \mu \mathrm{g} \mathrm{L}^{-1} \mathrm{Co}(\mathrm{II})$ solutions buffered at $\mathrm{pH} 7.0$ on a $10.0 \mathrm{~cm}$ mini-column and elution with $200 \mu \mathrm{L}$ of $2.0 \mathrm{~mol} \mathrm{~L}^{-1} \mathrm{HCl}$ at a flow rate of $2.0 \mathrm{~mL} \mathrm{~min}^{-1}$.

transfer from liquid to solid-phase at higher flow rates. Therefore, a flow rate of $2.0 \mathrm{~mL} \mathrm{~min}{ }^{-1}$ was selected for further studies.

The effect of elution flow rate was studied in the range 1.0-3.6 $\mathrm{mL} \mathrm{min}^{-1}$. Results have shown a linear increase in the absorbance up to $2.0 \mathrm{~mL} \mathrm{~min}^{-1}$ and then level off. The low sensitivity at flow rates lower than $2.0 \mathrm{~mL} \mathrm{~min}^{-1}$ is due to incompatibility between elution and nebulization flow rate. However, a flow rate of $2.0 \mathrm{~mL} \mathrm{~min}^{-1}$ was selected in further studied.

The effect of sample volume (loading time) on the absorption signal was tested in the range of $2-50 \mathrm{~mL}$ of $30 \mu \mathrm{g} \mathrm{L}^{-1}$ cobalt(II) solutions (1-25 min loading times) with a sample flow rate of $2.0 \mathrm{~mL} \mathrm{~min}{ }^{-1}$. Results showed that the signal increased linearly by increasing the sample loading time, which means that the retention efficiency was constant within this time interval. However, a $10 \mathrm{~mL}$ sample volume was selected in order to achieve a high sampling throughput with a reasonable degree of sensitivity. However, a longer loading time can be employed for samples with low concentration of cobalt.

The effect of the eluent injection volume was investigated in the range 50-300 $\mu \mathrm{L}$. It was found that the peak height response increased with an increase in $\mathrm{HCl}$ volume up to $100 \mu \mathrm{L}$ and then leveled off at higher injection volumes. Therefore, for subsequent works, $200 \mu \mathrm{L} \mathrm{HCl}$ with a concentration of $2.0 \mathrm{~mol} \mathrm{~L}^{-1}$ was injected as eluent and quantitative cobalt recoveries (98.5\%) were observed even for high concentrations. Two subsequent elutions with $200 \mu \mathrm{L} \mathrm{HCl} 2.0 \mathrm{~mol} \mathrm{~L}^{-1}$ on the same loaded column have shown that no cobalt was present in the second aliquot. This confirmed that the eluent injection into the column (as shown in Figure 1) could be successfully used for quantitative elution of the adsorbed cobalt. 
The effect of the column length on the cobalt signal was also investigated. $10 \mathrm{~mL}$ samples containing either 0.30 or $0.60 \mu \mathrm{g}$ of $\mathrm{Co}(\mathrm{II})$ were used in this study. In this study columns with different lengths $(4.0-12.0 \mathrm{~cm})$ but same inner diameters were used. Results showed that the retention efficiency increased with longer columns up to $9.0 \mathrm{~cm}$ and then remained constant. The increase in the sensitivity with increasing the column length is due to this fact that the longer columns have larger amounts of sorbent. Thus, a mini-column $10.0 \mathrm{~cm}$ long (containing $135 \mathrm{mg}$ of sorbent) was found to be ideal for efficient sorption of different amounts of cobalt in a $10 \mathrm{~mL}$ solution.

After establishing the best conditions for system operation, the influence of the ionic strength on the retention of cobalt(II) by the sorbent was investigated. For this purpose, the influence of $\mathrm{KNO}_{3}$ concentration on the analytical signal was investigated by preconcentration of sample solutions containing different concentration of $\mathrm{KNO}_{3}\left(0.0-0.50 \mathrm{~mol} \mathrm{~L}^{-1}\right)$. Results showed that concentrations up to $0.10 \mathrm{~mol} \mathrm{~L}^{-1}$ did not present significant effect on the analytical signal, and that approximately $20 \%$ signal decrease was observed when a $0.50 \mathrm{~mol} \mathrm{~L}^{-1} \mathrm{KNO}_{3}$ solution was used.

\section{Performance of flow manifold}

Under the optimum conditions, $\mathrm{pH} 7.0$, sample flow rate $2.0 \mathrm{~mL} \mathrm{~min}^{-1}$ and elution of retained cobalt(II) with $200 \mu \mathrm{L}$ of $2.0 \mathrm{~mol} \mathrm{~L}^{-1} \mathrm{HCl}$ at a flow rate of $2.0 \mathrm{~mL} \mathrm{~min}^{-1}$, some analytical parameters of the FI-online preconcentration system were studied.

Figure 6a shows the transient signal obtained from preconcentration of $10 \mathrm{~mL}$ sample solution containing $9.0 \mu \mathrm{g} \mathrm{L} \mathrm{L}^{-1}$ of cobalt(II) under the optimum conditions. For comparison purposes, the signal obtained with direct pneumatic nebulization of an acidic solution of cobalt $\left(1.0 \mathrm{mg} \mathrm{L}^{-1}\right)$ is also depicted in Figure 6b. Based on the

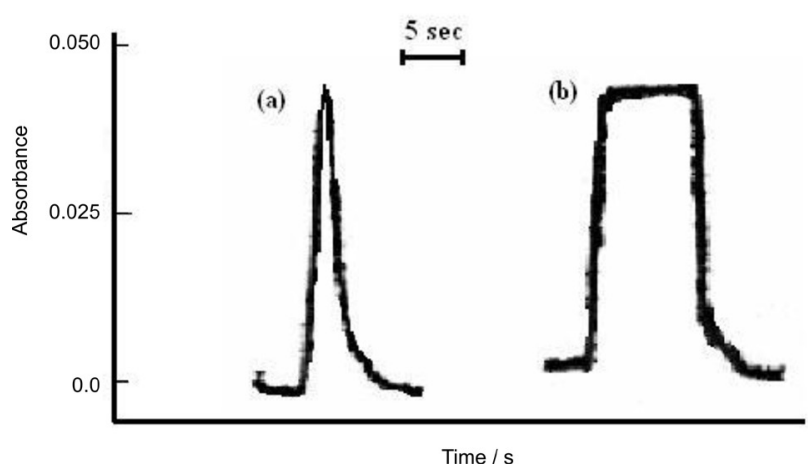

Figure 6. Absorbance-time response for (a) sequential preconcentration and elution of $\mathrm{Co}(\mathrm{II})$ solution $\left(10 \mathrm{~mL}, 9.0 \mu \mathrm{g} \mathrm{L} \mathrm{L}^{-1}, \mathrm{pH} 7.0\right)$, and (b) conventional nebulization of an acidic Co(II) solution $\left(1.0 \mathrm{mg} \mathrm{L}^{-1}\right)$. relative concentrations and respective peak height responses for both solutions, a preconcentration factor of about 110 was calculated.

The recovery was defined as the ratio between the analyte mass in the original sample solution and that in the concentrate after elution. For recovery experiments, $10.0 \mathrm{~mL}$ of a $50.0 \mu \mathrm{g} \mathrm{L}^{-1}$ cobalt solution was percolated through the column. The elution was performed, $1.0 \mathrm{~mL}$ of the concentrate containing the analyte was collected, and the cobalt in this solution was directly determined by FAAS. Under optimum conditions a recovery of $98.5 \%$ was obtained.

The lifetime of the mini-column packed with NAPdien was also evaluated. In this study, the analytical signal was recorded for preconcentration and elution of $10 \mathrm{~mL}$ standard solutions containing $3.0 \mu \mathrm{g}$ cobalt(II) over a time period of 200 days. Results obtained showed that the analytical signals were essentially constant in all these experiments. This shows the good performance of the minicolumn for at least 200 daily cycles and long lifetime of the sorbent. Thus, the column did not need any regeneration or repacking during all experiments.

\section{Linear ranges, detection limits and precision}

Using the manifold presented in Figure 1 under the optimum conditions, the calibration graph was linear over the ranges of 1.0-80.0 $\mu \mathrm{g} \mathrm{L}^{-1}$ with regression equation of $\mathrm{A}=2.03 \times 10^{-3} \mathrm{C}_{\mathrm{Co}(\mathrm{II})}+0.008$ and correlation coefficient of $0.9980(n=11)$ for the preconcentration of $10.0 \mathrm{~mL}$ sample solution. Another linear calibration graph with regression equation of $\mathrm{A}=5.32 \times 10^{-3} \mathrm{C}_{\mathrm{Co}(\mathrm{II})}+0.008$ and correlation coefficient of $0.9980(n=9)$ was found in the range of $0.30-40.0 \mu \mathrm{g} \mathrm{L}-1$ for the preconcentration of $20.0 \mathrm{~mL}$ sample solution. The limit of detection is given by $\mathrm{LOD}=\mathrm{KS}_{\mathrm{b}} / \mathrm{m}$, where $\mathrm{K}$ is a numerical factor chosen according to the confidence level desired, $\mathrm{S}_{\mathrm{b}}$ is the standard deviation of the blank measurements, and $\mathrm{m}$ is the slope of calibration curve. With ten replicate measurements of blank (distilled water containing $0.040 \mathrm{~mol} \mathrm{~L}^{-1}$ phosphate buffer with $\mathrm{pH}$ 7.0) and $\mathrm{K}=3$, LODs of 0.75 and $0.25 \mu \mathrm{g} \mathrm{L} \mathrm{L}^{-1}$ were established for sample volumes of 10 and $20 \mathrm{~mL}$, respectively. The relative standard deviations for ten replicate determinations of cobalt(II) at the 10.0 and $60.0 \mu \mathrm{g} \mathrm{L}-1$ levels were 4.7 and $3.3 \%$, respectively.

\section{Selectivity}

In order to assess the possible analytical application of the described procedure, the effects of various substances present in the real samples on the determination of 
Table 1. Interferences effects on Co(II) determination $\left(10.0 \mu \mathrm{g} \mathrm{L}^{-1}\right)$

\begin{tabular}{lc}
\hline Species & Tolerence limit (weight ratio) \\
\hline $\mathrm{K}^{+}, \mathrm{Na}^{+}, \mathrm{Cl}^{-}, \mathrm{NO}_{3}^{-}, \mathrm{NO}_{3}^{-}, \mathrm{SO}_{4}^{2-}, \mathrm{Br}^{-}$, & $1000^{\mathrm{a}}$ \\
$\mathrm{I}^{-}, \mathrm{Ca}^{2+}, \mathrm{Ba}^{2+}, \mathrm{Sr}^{2+}, \mathrm{Mg}^{2+}, \mathrm{Mn}^{2+}, \mathrm{Hg}^{2+}$, & \\
$\mathrm{Cd}^{2+}, \mathrm{Pb}^{2+}, \mathrm{Zn}^{2+}, \mathrm{As}^{3+}, \mathrm{Bi}^{3+}, \mathrm{Cr}^{3+}$, & \\
$\mathrm{MoO}_{4}^{2-}, \mathrm{WO}_{4}^{2-}$ & \\
$\mathrm{Citrate}$ & 800 \\
$\mathrm{Ag}^{+}$ & 600 \\
$\mathrm{Al}^{3+}$ & 50 \\
$\mathrm{Fe}^{3+}, \mathrm{Cu}^{2+}, \mathrm{Ni}^{2+}$ & 25 \\
$\mathrm{EDTA}^{2+}$ & 1 \\
\hline
\end{tabular}

aximum limit tested.

cobalt(II) were investigated. Synthetic mixtures of solutions containing $10.0 \mu \mathrm{g} \mathrm{L}^{-1}$ of cobalt(II) and different amounts of diverse ions were used as sample. The tolerance limit was defined as the concentration of the added ions causing a change in the Co absorbance higher than $\pm 5 \%$. Results (Table 1) demonstrate that the presence of large concentrations $\left(10 \mathrm{mg} \mathrm{L}^{-1}\right)$ of alkaline, alkaline earth, and transition metals have no significant effect on the preconcentration of cobalt. Only $\mathrm{Fe}^{3+}, \mathrm{Ni}^{2+}$, and $\mathrm{Cu}^{2+}$ caused variation in the cobalt(II) signal. Additional studies showed that the interference effect of $\mathrm{Fe}^{3+}$ can be reduced up to 200 -fold using $8.0 \mathrm{mg} \mathrm{L}^{-1}$ of citrate ion. Thus, the analysis of water samples was carried out in the presence of $8.0 \mathrm{mg} \mathrm{L}^{-1}$ of citrate ion.

\section{Real samples analysis}

To study the accuracy of the method and the possible effects from real matrices, the proposed method was applied to the determination of cobalt(II) in spiked water samples and sodium chloride solutions using the standard additions method. For this purpose, the aliquots of sample solution ( $\mathrm{pH}=7.0$ ) were spiked with cobalt(II) at different concentrations and $8.0 \mathrm{mg} \mathrm{L}^{-1}$ citrate ion (as masking agent). Results were tabulated in Table 2, which show the applicability of the proposed method for determination of cobalt(II) in water samples.

\section{Conclusions}

The practical applicability of using a chelating polymeric material containing N,N-bis(naphtilidineimino) diethylenetriamine anchored with chloromethylated polystyrene polymer (PS-NAPdien) beads as a packing material for FI on-line preconcentration coupled to FAAS for trace cobalt determination was successfully evaluated and demonstrated. The proposed sorbent possesses high stability,
Table 2. Addition-recovery experiments

\begin{tabular}{|c|c|c|c|}
\hline Sample & $\begin{array}{l}\mathrm{Co}(\mathrm{II}) \text { added / } \\
\left(\mathrm{mg} \mathrm{L}^{-1}\right)\end{array}$ & $\begin{array}{l}\text { Co(II) recovered / } \\
\left(\mathrm{mg} \mathrm{L}^{-1}\right)\end{array}$ & $\begin{array}{c}\text { Recovery / } \\
(\%)\end{array}$ \\
\hline \multirow[t]{4}{*}{ Tap water(I) } & & $<$ LOD & \\
\hline & 0.0040 & $0.0042( \pm 0.0003)$ & 105 \\
\hline & 0.012 & $0.012( \pm 0.001)$ & 100 \\
\hline & 0.028 & $0.029( \pm 0.001)$ & 103.6 \\
\hline \multirow[t]{4}{*}{ Tap water(II) } & & $<$ LOD & \\
\hline & 0.036 & $0.036( \pm 0.002)$ & 100 \\
\hline & 0.044 & $0.045( \pm 0.001)$ & 102.3 \\
\hline & 0.060 & $0.059( \pm 0.002)$ & 98.3 \\
\hline \multirow[t]{3}{*}{ Spring water } & & $<$ LOD & \\
\hline & 0.016 & $0.015( \pm 0.001)$ & 94.0 \\
\hline & 0.026 & $0.028( \pm 0.005)$ & 107.7 \\
\hline \multirow{3}{*}{$\begin{array}{l}\text { Bottled natural } \\
\text { mineral water }\end{array}$} & & $<\mathrm{LOD}$ & \\
\hline & 0.036 & $0.034( \pm 0.002)$ & 94.4 \\
\hline & 0.066 & $0.064( \pm 0.008)$ & 97.0 \\
\hline \multirow{4}{*}{$\begin{array}{l}0.50 \mathrm{~mol} \mathrm{~L}^{-1} \mathrm{NaCl} \\
\text { solution }\end{array}$} & & $<\mathrm{LOD}$ & \\
\hline & 0.0050 & $0.0047( \pm 0.001)$ & 94.0 \\
\hline & 0.015 & $0.016( \pm 0.002)$ & 106.7 \\
\hline & 0.045 & $0.0041( \pm 0.007)$ & 91.1 \\
\hline
\end{tabular}

and it can remain stable in strongly acidic and basic media. This is a significant advantage over silica based sorbents, which are unstable due to either hydrolysis of the bonded chain at low $\mathrm{pH}$ or dissolution of silica at high $\mathrm{pH} .{ }^{16-19}$ The chemical inertness, fast adsorption, and desorption kinetics of the proposed sorbent make it attractive in on-line column preconcentration systems. The column also has long lifetime without the need for pre-conditioning or activation steps. A high preconcentration factor (110) and high recovery (98.5\%) were obtained using the developed method. It proved to be simple, rapid, and accurate for cobalt(II) determination in water samples with few interferences.

\section{Acknowledgements}

The authors are thankful to the Shahrood University of Technology Research Council for the support of this work.

\section{References}

1. Pereira, M. G.; Arruda, M. A. Z.; Microchim. Acta 2003, 141, 115.

2. Fang, G. Z.; Baasner, J.; Welts, B.; Anal. Chim. Acta 2003, 481, 273.

3. Goswami, A.; Singh, A. K.; Anal. Chim. Acta 2002, 454, 229.

4. Liu, P.; Su, Z.; Wu, X.; Pu, Q.; J. Anal. At. Spectrom. 2002, 17, 125. 
5. Fang, Z.; Flow Injection Atomic Absorption Spectrometry, John Wiley and Sons Ltd.: West Sussex, England, 1995.

6. Zhang, S.; Pu, Q.; P.; Liu, Q.; Sun, Su, Z.; Anal. Chim. Acta 2002, 452, 223.

7. Ferreira, S. L. C. V.; Lemos, A.; Santelli, R. E.; Ganzarolli, E.; Curtius, A. J.; Microchem. J. 2001, 68, 41.

8. Camel, V.; Spectrochim. Acta, Part B 2007, 58, 1177.

9. Ye, Y. X.; Ali, A. ; Yin, X. F.; Talanta 2002, 57, 945.

10. Liu, X. Z; Fang, Z. L.; Anal. Chim. Acta 1995, 316, 329.

11. Sperling, M; Yin, X. F.; Welz, B.; J. Anal. At. Spectrom. 1991, 6,615 .

12. Gonzalez, M. M.; Gallego, M.; Valcarcel, M.; J. Anal. At. Spectrom. 1999, 14, 711.

13. Farias, G. M.; Cerutti, S.; Gasquez, J. A.; Olsina, R. A.; Martinez, L.D.; At. Spectrosc. 2004, 24, 213.

14. Cerutti, S.; Moyano, S.; Gasquez, J. A.; Stripeikis, J.; Olsina, R. A.; Martinez, L. D.; Spectrochim. Acta, Part B 2003, 58, 2015.

15. Ghaedi, M.; Ahmadi, F.; Soylak, M.; J. Hazard. Mater. 2007, 147, 226.

16. Ghaedi, M.; Ahmadi, F.; Shokrollahi, A.; J. Hazard. Mater. 2007, 142, 272.

17. Jarvis, K. E.; Williams, J. G.; Alcantara, E.; Wills, J. D.; J. Anal. At. Spectrom. 1996, 11, 917.

18. Gurnani, V.; Singh, A.K.; Venkataramani, B.; Talanta 2003, 61, 889.

19. Tsakovski, S.; Benkhedda, K.; Ivanova, E.; Adams, F. C.; Anal. Chim. Acta 2002, 453, 143.

20. Benkhedda, K.; Goenaga Infante, H.; Ivanova, E.; Adams, F.; Fresenius J. Anal. Chem. 2000, 368, 288.

21. Benkhedda, K.; Infante, H. G.; Ivanova, E.; Adams, F.; J. Anal. At. Spectrom. 2000, 15, 429.
22. Yan, X. P.; Van Mol, W.; Adams, F.; Lab. Robotics Automat. 1997, 9, 191.

23. Shabani, A. M. H.; Dadfarnia, S.; Dehghan, K.; Talanta 2003, $59,719$.

24. Dadfarnia, S. Jafarzadeh, M. H.; Microchem. J. 1999, 63, 226.

25. Brasil, J. C.; Do Nascimento, P. V. B.; Santelli, R. E.; Quim. Anal. 1996, 15, 135.

26. Trojanowicz, M.; Pyrzynska, K., Anal. Chim. Acta 1994, 287, 247.

27. Safavi, A.; Iranpoor, N.; Saghir, N.; Momeni, S.; Anal. Chim. Acta 2006, 569, 139.

28. Cerutti, S.; Orsi, R. F.; Kaplan, M.; Gasquez, J. A.; Olsina, R. A.; Martinez, R. A.; Instrum. Sci. Technol. 2004, 32, 401.

29. Lemos, V. A.; Santos, J. S.; Nunes, R. S.; de Carvalho, M. B.; Baliza, P. X.; Yamaki, R. T.; Anal. Chim. Acta 2003, 494, 87.

30. Karatepe, A. U.; Soylak, M.; Elci, L.; Anal. Lett. 2002, 35, 2363.

31. Jimenez, M. S.; Castillo, J. R.; J. Anal. At. Spectrom. 1997, 12, 1397.

32. Praveen, R. S.; Daniel, S.; Rao, I. P.; At. Spectrosc. 2006, 27, 35 .

33. Cassella, R. J.; Salim, V. A.; Jesuino, L. S.; Santelli, R. E., Ferreira, S. L. C.; de Carvalho, M. S.; Talanta 2001, 54, 61.

34. Yebra-Biurrun, M. C.; Lab. Robotics Automat. 1998, 10, 299.

35. Akelah, A.; Moet, A.; Functionalized Polymers and their Applications, Chapman and Hall: Great Britain, 1990.

36. Coleman, W. M.; Boggess, R. K.; Hughes, J. W.; Taylor, L. T.; Inorg. Chem. 1981, 20, 700.

37. Benabdallah, T.; Al-taiar, A. H.; Reffas, H.; S. Afr. J. Chem. 2004, 57, 33 .
Received: May 9, 2009

Web Release Date: December 11, 2009 